\title{
A Case Study of the Vietnamese in Toronto: Contesting Representations of the Vietnamese in Canadian Social Work Literature
}

\author{
ANH NGO
}

\begin{abstract}
This article argues that the lived experiences and challenges of the Vietnamese community in Toronto are not reflected in the social work literature that continues to represent them as exceptional refugees. Over forty years after the fall of Saigon, a qualitative research study, "Discrimination in the Vietnamese Community, Toronto," reveals that the Vietnamese community continues to experience intergroup conflicts stemming from war- and displacement-mediated identities of region, class, and temporal periods of migration. A critical review of the social work literature, using the theoretical lens of critical multiculturalism, traces the construction of the Vietnamese Canadians as successful "boat people" as part of the larger narrative of multiculturalism. This discourse of exceptionalism allows the needs of those who fall outside the constructed identity to remain unseen and underserved. Participant responses from this small pilot study will inform future investigation into the impact of intergroup conflicts hidden under the veneer of successful integration and adaptation of refugee and migrant groups.
\end{abstract}

\section{Résumé}

Cet article propose que les expériences vécues et les défis affrontés par la communauté vietnamienne à Toronto ne sont pas reflétés dans la documentation sur le travail social qui continue de les représenter en tant que réfugiés exceptionnels. Plus de quarante ans après la chute de Saigon, une étude de recherche qualitative intitulée
"Discrimination in the Vietnamese Community, Toronto" (la discrimination dans la communauté vietnamienne à Toronto) permet de constater que la communauté vietnamienne continue d'éprouver des conflits intergroupes, façonnés par la guerre et le déplacement, qui découlent des identités régionales, de classe sociale et des différentes périodes de migration. Un examen critique de la documentation sur le travail social, à l'aide de l'optique théorique du multiculturalisme critique, retrace l'élaboration $d u$ discours sur les Canadiens d'origine vietnamienne en tant que «boat people» ou réfugiés de la mer qui ont réussi, comme faisant partie du discours général sur le multiculturalisme. Ce discours fondé sur l'exceptionnalisme empêche de rendre visible et de considérer les besoins de ceux qui se situent hors de cette identité préalablement construite. Les réponses des participants à cette étude pilote de taille limitée alimenteront des recherches postérieures sur l'impact des conflits intergroupes dissimulés sous l'apparence de l'intégration et de l'adaptation réussie des groupements de migrants et réfugiés.

\section{Introduction}

ver forty years after the official end of the war in Vietnam as marked by the 30 April 1975 fall of Saigon, the case of the Indochinese refugee movement in Canada is still widely regarded as an example of not only the resiliency and endurance of the human spirit, as witnessed in the refugees themselves, but also the compassionate and altruistic gestures of the Canadian population. In this article, I ask how this growing and diverse group of 
people continue to be essentialized under a singular identity of "refugeehood" and how this essentialization continues to affect them. ${ }^{1}$ I argue that the social work literature on Vietnamese Canadians, informed by the narrative of multiculturalism, continues to construct them as exceptionally legitimate and successful refugees, thus allowing lived experiences that fall outside of this identity to remain hidden. The participant data from a local study in intergroup discrimination refute this singular identity by highlighting regional, class, and temporal migration conflicts as they relate to lingering tensions from the Vietnam War. The implication of this narrow construction of a particular group is that it prevents educators and researchers from seeing the diverse struggles and needs of the Vietnamese Canadian community. First, I will review the demographics of the Vietnamese in Canada. Next, I will examine the findings of the literature review for examples of complicity in upholding the exceptional refugee narrative of the Vietnamese. I will then provide an in-depth review of the community-based study of the Vietnamese population in Toronto to contest the literature. A discussion on the experienced exclusion from community-belonging due to war- and displacement-mediated differences will highlight the diversity and continued conflicts within this population. I will conclude by asserting the implications of social work knowledge production in marginalizing the very communities that we aim to support.

\section{The Vietnamese in Canada}

In the 2011 census, the population of Vietnamese Canadians is estimated at over 220,000 on the basis of self-reporting of ethnic origin. ${ }^{2}$ This community's largest concentration of growth was during the refugee period. After the 1990s, many more arrived to Canada at a steady pace. A small cohort came as Convention refugees immediately after the end of the war in 1975/6, but most of the refugees arrived in 1979 and 1980. This group, commonly referred to as the Indochinese refugees or "boat people," came as part of the initial 60,000 people admitted under the special immigration partnerships between government and public, culminating in 125,000 by the end of this program in the early 1990 s. $^{3}$ Since the end of the Indochinese refugee period of the 1980 os to the 1990 , from the 1990 s to 2014, about 74,000 continued to arrive from Vietnam under the different immigration classes of family reunification, skilled workers, and economic migrants. ${ }^{4}$ In 2011, there were 70,725 persons of Vietnamese ethnic origin in the Greater Toronto area, according to the National Household Survey. 5 The City of Toronto alone counts 45,270 persons of Vietnamese ethnic origin, with 23,575 reporting Vietnamese as a mother tongue. ${ }^{6}$ In Toronto, Vietnamese ranked fifteenth in languages at home.7 Across Canada, Vietnamese ranked in the top 12 most languages spoken at home in five of the six largest census metropolitan areas of Montreal, Vancouver, Calgary, Edmonton, and Ottawa-Gatineau. ${ }^{8}$ Vietnamese refugees, and later migrants, arrived in Canada from different regions of Vietnam, class statuses, gender identities, and political allegiances. In the following section, I will review the literature that I argue upholds the discourse of Vietnamese as exceptional "boat people" refugees. This narrative reinforces the assumption that all Vietnamese Canadians are former refugees, despite the statistics that report close to 40 per cent of Vietnamese migrants to Canada arrived after the refugee period under different circumstances of migration.

\section{Constructing Vietnamese Canadians}

Scholars such as Sakamoto and Valverde critique the social work literature on its construction of communities as problem-centred groups in need of support. ${ }^{9}$ In Tsang's critique of North American social work literature, he traced the hegemonic construction of Chinese persons into a "dossier" to be known and to be practised on. ${ }^{10}$ While there is no definitive body of literature that is commonly known as "social work literature," this article draws upon academic work, including peer-reviewed journal articles, that social work practice and research relies heavily upon. The academic works may include the disciplines of education, health, migration studies, and refugee studies. The databases chosen for critical review are Social Services Abstracts, Sociological Abstracts, Pyschinfo, and Applied Social Sciences Index and Abstracts. An examination of keywords related to Vietnamese immigrants and/or refugees to Canada in these four databases was conducted among articles published from 1970 to 2015 . This search yielded 85 articles. A critical reading of the literature that informs social work research and practice reveals the dominant construction of the Vietnamese exceptionalism as legitimate and productive refugees several decades after the end of the Vietnam War.

\section{Vietnamese as Legitimate Refugees}

The social work literature on Vietnamese Canadians produced them as legitimate refugees. This construction, set within the broader context and discussion of "bogus" refugees or refugee smugglers, contributes to the discourse of the Vietnamese exceptionalism. This legitimacy is narrated in their rightful flight and suffering in their countries of origin. In describing the Vietnamese refugees' departure from their country of origin, the theme of a rightful flight, which constitutes legitimate "refugeeness," was used repeatedly. ${ }^{11}$ Beiser, a respected expert on the Vietnamese Canadians, contributes to this conversation in his work to draw attention and support for the refugees, and states that the 
Vietnamese "refugees are survivors of oppression, plunged into poverty, purified by their sufferings, and boundlessly grateful for safe haven." ${ }^{2}$ Chan and Indra describe the unprecedented acceptance of these refugees: "Never before had the Canadian public become so actively involved, both through the private sponsorship of refugees and through massive volunteer involvement in settlement activities."13 The discussion of legitimate refugees contrasts with, and sets them apart from, other arrivals in the official context of "bogus" refugees, smugglers, and "economic" migrants. ${ }^{14}$

Few critical works contest the Vietnamese legitimacy, with the exception of Allen and Hiller who, in 1985, provided an early critique of the legitimate refugee discourse of the Vietnamese by tracing the individuals' process of becoming a refugee. ${ }^{15}$ The researchers interviewed 70 refugees who had arrived in Canada and described them as active subjects in the decision-making process, in contrast with the literature's common portrayal of a spontaneous flight. Strategic organization then occurs, such as the grouping of family and friends into escape ventures, solicitation of means of transport, and the payment and bribing of officials. These activities have since been cited as evidence of refugee smuggling operations in the 1999 case of Fujian Chinese refugees and the 2009 case of the Tamil refugees, yet Vietnamese refugees are rarely, if ever, remembered as such. ${ }^{16}$ I argue this deliberate forgetting is part of the larger nation-building project.

Vietnamese exceptionalism was constructed in the $1980 \mathrm{os}$ to serve Canada's nation-building project on the international stage as a leader in humanitarian rescue and refuge. During the time of destructive American action against another sovereign nation, Canada's role as an ally and chief arms supplier in the Vietnam War was quietly ignored, as the focus was kept on its humanitarian rescue and resettlement of war-created refugees. ${ }^{17}$ Critical theorists of Canadian multiculturalism vigorously interrogate the technologies of Canada's nation-building, one of which is the construction and maintenance of the "desirable" versus the "undesirable Other" to the nation..$^{18}$ Racialized persons, immigrants, and newcomers have variously been constructed as outside the nation. Canadian multiculturalism then is deconstructed as a governing tool in which those outside the nation are managed to serve, paradoxically, the nation but to never fully belong within it. A well-known example is Canada's founding myth that has reinforced and continues to reinforce the narrative of Canada as a vast, empty nation founded by French and British colonial settlers. ${ }^{19}$ For instance, Haque's meticulous examination of government materials (transcripts of hearings, memos, reports, and policy documents) produced during the 1970 s Commission on Bilingualism and Biculturalism reveals the deployment of this language policy to reinforce and, in effect, legislate the myth of two founding fathers under official bilingualism, with the rest of the nation as "multicultural Others." ${ }^{20}$ Indigenous claims to sovereignty and the land are erased, as well as the history of Black indentured persons, Chinese labourers, and racialized settlers. These groups have contributed tremendously to this nation in material, cultural, and social ways, yet their histories are discursively minimized as their descendants continue to struggle with racism and xenophobia as outsiders to the nation. The discourse on the Vietnamese as exceptional is an integral part of this over-arching governing tool of multiculturalism, which constructs and upholds them as legitimate refugees to be positioned innately against other racialized groups who are constructed as "bogus" refugees. From the literature, social work educators and researchers may know this group only as "legitimate" refugees, thus Vietnamese Canadians who have differing migration experiences may hesitate to seek social service help for fear of being misconstrued. Within social work literature, not only are Vietnamese Canadians portrayed as legitimate refugees, but they are productive as well.

\section{Vietnamese as Productive Refugees}

The literature problematically constructs Vietnamese Canadians as productive refugees who contribute to the capitalist nation. The literature on the Vietnamese describes them as a model minority in education, refugee adaptation, and participation in capitalism. ${ }^{21}$ Productive refugees are able to overcome their traumas and hardship to gain financial independence after a period of resettlement, no longer a burden on the state for charity. The frequent description of the refugees' dire situations under communism compared to their successes in capitalist Canada implies movement, positive difference, and progress. The Vietnamese refugees are described as "pathetic wretches struggling to escape from a nation which sought to enslave its own population" where the evil is communism that created the conditions forcing the flight of the nation's people. ${ }^{22}$ Beiser, Johnson, and Turner describe the Vietnamese refugees as "survivors of terror, upheaval, and forced incarceration." 23 In infantilizing the refugees, Montgomery's methodology compares the relationship of theories of education to successful economic adaptation, comparing the data on refugees with those from previous studies on youth. This evokes images of Vietnamese refugees as underdeveloped, uneducated, and in stages of education and career readiness similar to those of the youths of Canada. ${ }^{24}$ Thirty years after the Vietnam War, Beiser recounts the model refugees' transition into model immigrants: "Within ten years, employment rates for the former Southeast Asian refugees were higher than the Canadian average, and there was no apparent difference 
in the rate of Southeast Asians versus native-born Canadian use of public services." 25 In appealing to the public on the successes of refugee rescue and resettlement, these scholars instead contribute to the discussion of this group as "exceptional," thus hiding the material struggles many of them continue to have as the result of structural and systemic barriers in Canada.

Model minority theorists demonstrate how the construction of Asian Canadians as the desirable immigrant subject dismisses and delegitimizes the political claims of Indigenous peoples and nonconforming racialized others. Under the model minority discourse, Asian Canadians' successes are attributed to their "culture" of hard work, self-reliance, and high value given to schooling for their children. ${ }^{26}$ Asian Canadians' successes are linked to "cultural" factors, thus leaving implicit the understanding that others groups' problems are also linked to cultural factors rather than structural racism, sexism, homophobia, and classism. In emphasizing this Pon states, “The Asian 'model minority' discourse also serves to reinforce the liberal belief that Canada and its institutions such as schools are accommodating, fair, and accessible to all those who work hard enough." ${ }^{27}$ Within the Vietnamese community, the model minority narrative does not allow for the space to voice the concerns that disrupt the images of them as a successful case of Canadian immigration and settlement. Accordingly, the Vietnamese communities are unable to discuss the lingering internal conflicts from the Vietnam War as a systemic issue in the context of multicultural Canada. Furthermore, the model minority discourse constructs the Vietnamese community who are transformed from the backwardness of communism into civilized citizens. Vietnamese "boat people" are therefore viewed as both legitimate and productive refugees who "pay back" the rescuing state and nation for their freedom. ${ }^{28}$ The social work literature on the Vietnamese communities is unable to recognize the needs of those who fall outside the celebrated and productive Vietnamese refugee group.

\section{Previous Studies on Intra-Community Diversity}

Few studies have queried the differences and conflicts within the Vietnamese Canadian community. Beiser, Noh, Hou, Kaspar, and Rummens's 2001 quantitative study based on local data queries the experience of discrimination by Vietnamese Canadians. They report 26 per cent of Southeast Asian refugees have had at least one experience of racial discrimination. ${ }^{29}$ Qualitatively, Phan interviewed school-aged youths in British Columbia and reported their stories of structural racism experienced from Caucasian teachers and peers in the school setting. ${ }^{30}$ Lay and Nguyen came closer to exploring intercommunity discrimination in an early quantitative study of Ontario university students who report intergroup discrimination as "hassles" as related to measures of depression..$^{11}$ These hassles, as it relates to Vietnamese culture, include language barriers within the community and exclusion based on not understanding idioms, jokes, slang, and an overall feeling of being left out. In a related study, Nolin analyzes the inter-group diversity due to country-of-origin conflicts as "ruptures" among Guatemalan migrants in Ontario. ${ }^{32}$ She argues that the experiences of having lived under political violence and repression, and the current state of political violence in Guatemala, continue to have effects on the lives of those in Canada in the form of community silences and mistrust. In related Vietnamese American studies, Espiritu explores intergroup diversity using the concept of "ethnicization" as a process of ethnic identity formation that includes differentiations in "the internal differences, social background, and class position of individuals within a minority group both before and after they arrive" in her study of the settlement successes of Chinese-Vietnamese Americans and Vietnamese Americans. ${ }^{33}$ Similarly, Vietnamese Canadians who have lived through the Vietnam War prior to migrating to Canada can be expected to have intergroup conflicts and division, an experience that has not been well represented within the literature. Little work has been done in Canada to analyze the heterogeneity of this community as it contributes to divisions on these grounds.

By supporting the conversation of Vietnamese refugees' exceptionalism, the academic literature contributes to a hegemonic narrative for this group of people. The following will be a detailed overview of a local study with the Toronto Vietnamese and a discussion of participants' experiences of intergroup differences and exclusion. These differences are mediated by the events of the Vietnam War that directly challenge the single narrative in the literature of this group as "legitimate" refugees and successful "boat people." Participants reported experiences of discrimination and exclusion within the community stemming from differences in regional origin, class status pre-migration, and temporal periods of migration. This will engage with the above literature reviewed that portrays the Vietnamese within one static refugee identity.

\section{Method}

In 2013, a local agency received a one-year grant to build the community's capacity by identifying and addressing exclusion and discrimination within the Vietnamese community to work towards collectivizing on shared challenges. This agency had identified intra-community conflict stemming from war- and migration-mediated identities as an impediment to the achievement of well-being for its Vietnamese clients and stakeholders. The case was made to the City of 
Toronto's Community Funding Program, who had also heard of difficulties in coalition-building within the Vietnamese community. An exploration of exclusion and discrimination within the Vietnamese community was needed to assess the impact of these issues and start a dialogue with community members. The project consisted of a series of focus group meetings, interviews, and submitted responses on individuals' experiences of community, conflict, division, and discrimination. The agency's Community Advisory Committee of five members oversaw the project. In the interest of participant confidentiality in a community of this size, identifying data have been removed, which include the real names of participants, the name of the agency, and the name of the specific grant under which this project was funded.

The project consisted of focus groups and in-depth interviews using a semi-structured interview guide. In total, 28 participants attended the four focus groups, and 10 participants consented to an in-depth interview. Of the participants, over 60 per cent were women, the mean age was 49.4 , and the mean length of time in Canada was 14.5 years. Of the in-depth interview participants, 50 per cent were women, the mean age was 44.7 , and the mean length of time in Canada was 22.7 years. There was a diversity of participants from the different parts of Vietnam as they selfidentified as originating from one of the three main regions: North, Central or South. The focus groups were audiotaped and followed a loose discussion guide. The focus group interviews averaged two hours in length. Eight individual interviews were audiotaped, one was documented with interviewer memos, and one was documented with interviewer memos and participant-written follow-up in the form of an email. A standardized interview guide was used with five key focus points that allow for a participant-led discussion alongside the guide. The individual interviews averaged 1.5 hours in length. An incentive of twenty dollars was provided to all participants to acknowledge the value of their contribution. All focus groups and interviews were conducted in Vietnamese. The audiotaped data were transcribed first in Vietnamese and then translated into English. Participants shared their experiences of discrimination based on differences of regional origin in Vietnam, class, and period of migration. They also shared the impact of such discrimination from experiences of social exclusion to threats of violence.

\section{Discussion}

\section{Regional Identity Related to War}

Participants of the community study in Toronto reported experiences of exclusion based on their regional identity in Vietnam as relating to the events of the Vietnam War. Colonial domination and division of the country by several empires officially segregated the country into three regions: North (Bắc), Central (Huế or Trung), and South (Nam). During the major conflict that drove the Indochinese refugees to Canada, the country was divided into two, just south of the 17 th parallel, slightly north of the ancient imperial city of Hue in the Central region. The Geneva Accord of 1954 dictated this division, which continued until the end of the war in Vietnam in 1975. ${ }^{34}$ Participants reported that it was important to determine which region one originated from, as there is a common public perception that those from the Central and South Vietnam are legitimate refugees from the Vietnam War, while those from North Vietnam are naturally assumed to be communist and do not truly belong to the Vietnamese Canadian community.

Participants of the local study reported the common assumption within the diaspora that persons from North Vietnam are typically considered to be the minority in the Vietnamese community, as those from Central and South Vietnam were the initial groups that fled Vietnam following the end of the war. Regional dialects reveal region of origin. Participants reported the equating of a Northern dialect to a former if not current communist allegiance.

Xuân, a North Vietnamese woman, described a negative experience with a Vietnamese Canadian public employee who interrogated her political background in Vietnam when she called the public agency to seek services: "For me, I understand him. I am not mad at him. The truth is that many people assumed that the Northern people are people in the Communist party. Even just today, I was curious and didn't know what so-call the day Quốc Hận [National Grief] April zoth in City Hall is about. I was curious and in previous years' newspapers, I found out that people are getting together and they come to the Vietnamese embassy with their slogan against Communists." 35

Here, Xuân had described the annual commemoration and protest that some of the diaspora host each year to mark the fall of Saigon and to call on the Canadian government to boycott or to sanction Vietnam. Diasporic activities, which aim to influence the politics in the country of origin, in this instance, also harm some members of the diaspora itself.

Some participants described the surveillance and unwanted attention drawn to persons with a North Vietnamese dialect. Phủ, a South Vietnamese woman, stated, "Sometimes, when I hear they were speaking Northern voice, or laughing out loud or even swearing in the street, I don't care either. I just thought that they'd better not to do so." ${ }^{36}$ In this she suggests that a North Vietnamese person needs to conform, to conduct oneself "properly," to not draw attention to oneself within the Vietnamese community. She did not specify the consequences, but suggests that in order to fit in, North Vietnamese persons must "behave" at all 
times in public. On the other side of the regional difference, those who use the North Vietnamese dialect reported being teased, with the result that the individual feels discriminated against. An, a woman in her late twenties, reported, "When I got a job in the community, some colleagues told me that I am a Northern girl (cô gái bắcky). I knew that they were teasing me with that term, they were joking, but just half-joking. After all, I knew that they were discriminating against me. Anyway, I ignored it. I kept working on my own." 37 The consequence of this surveillance and unwanted attention to regional origin due to differences in dialect and used is self-exclusion from social participation.

Regional differences in the Vietnamese language ultimately distinguish how individuals belong to postwar Vietnam and to Canada. Taken together with the division of the country during the Vietnam War, with North Vietnam as the communist enemy and South Vietnam as the democratic ally to the United States, North Vietnamese persons today report feeling unwanted scrutiny and exclusion based simply on how they speak. Critically, both Northern Vietnamese participants discussed above, Xuân and An, are female and reported being directly interrogated and harassed for their dialects, while the male North Vietnamese respondents shared a general perception without offering direct experiences of harassment. The regional differences exacerbated by events of the Vietnam War contest the literature on Vietnamese Canadians as homogenous refugees fleeing communism. The experiences of local Vietnamese Canadians of alienation, exclusion, and discrimination when they do not fit into the legitimate refugee narrative remain hidden. The next facets of diversity reported among participants-class and migration period-are also experienced as divisive and discriminatory.

\section{Class and Migration Differences}

Class differences in Vietnam became complicated in the aftermath of the war in Vietnam first as the result of the refugee condition and later of massive changes in the global economy. Class positions were upended when the political and military elite of South Vietnam found themselves on the losing side of the war and arrived in Canada as refugees, often leaving all their possessions behind. Suddenly, the South Vietnamese elite found themselves in a socioeconomic status similar to that of as the lower classes of farmers and labourers. Yet class discrimination was still experienced within the refugee cohort. Hùng, a male senior participant who arrived as a "boat person," recollected, "When I just came to Canada, Vietnamese people who had come before 1975 by airplane looked at us with different eyes. They said, 'The slow buffalo has to drink muddy water.' They said those who came late did not get the benefits like those who came earlier nor ... were [they] as rich and well-educated as people who came first." 38 The use of this common Vietnamese proverb to compare people to oxen is offensive and derogatory.

To further complicate the experience and effect of class in this community, the recent global context of a rising Vietnamese economy meant that those who were the elite of South Vietnam and who had fled in the 1980s are now faced with the reality that some of those who stayed on have prospered greatly. The Vietnam that the Indochinese refugees left behind is rapidly moving away from an impoverished war-torn Third World country towards becoming a regional and global economic player. ${ }^{39}$ Now middle-class Vietnamese are making their way to Canada via the economic migration routes. Participants reported they had commonly heard the stereotype that today's wealthy Vietnamese have profited under the current regime in Vietnam and therefore they must be communists. As Minh sums up the discussion, "Is it because they hate communism, they hate as well people who have lived in that country who they thought [were] already living with the communist regime and more or less accepted that regime? An indisputable fact is that most of the recent newcomers, especially the skilled workers or investors, and even overseas students [were] ... considered ... to have money [they were considered as part of the] higher class [of] the country." 40 Minh arrived in Canada through the skilled-worker program in the $2000 \mathrm{~s}$ and reported that he faced suspicion and animosity from the Vietnamese Canadians he encountered at the time, as they did not believe he simply applied for and obtained immigration status into Canada without special help from officials in Vietnam.

The period of migration to Canada is directly related to class differences. The experience of exclusion based on this class difference is mediated by the legacy of the Vietnam War. Like regional differences, the way the Vietnamese language is used implies the historical and political period during which individuals migrated to Canada. Following the end of the war, during the period in Vietnam called the Reunification, language changed in subtle ways across the country. Phủ, a man from South Vietnam, reported how he stood out from the present Vietnamese in Toronto simply by his vocabulary: "When I just came here, I was considered by old settlers as 'New Vietnamese.' When I used new terms in my daily talk, they labelled me as Việt Cộng. Now I do the same to new Vietnamese newcomers."41 The Viẹt Cộng was the political and military force that fought against the South Vietnamese government in South Vietnam. Hai, another South Vietnamese who, like Phủ, arrived after the refugee period, shared his experience of exclusion when he tried to join in the community action on the issue of the contested Paracel and Spratly Islands. He stated he was told 
at the local event, "Protests against China invasion of Hoàng $\mathrm{Sa}$ [Paracel], Truiơng Sa [Spratly] is our concern. You guys, newcomers, don't need to join us, because you guys sold lands and islands to China. Why do you need to be here to protest?"42 Hai's and Phü's experiences share the theme of perceived betrayal of the true Vietnam. Within the diaspora, the historical Việt Cộng are commonly insulted as the people who sold their country (người bán nuớc) during the war, yet today, while Việt Cộng no longer exist, at least not in the official sense, members of this community continue to insult one another as such.

Class differences within the Vietnamese Canadian community have not been represented in the social work literature. Participants reported that complexities of class diversity contributed to their experiences of discrimination. The difference in class status transferred from the country of origin is ignored in the literature's continued construction of Vietnamese Canadians as impoverished refugees who have now succeeded in the Canadian capitalist economy. The temporal effect of migration for this community is important, as those who arrived as Indochinese refugees in the 1980 have been assigned the mantel of the "legitimate" refugees, while those who arrived later are looked down upon as "economic" migrants. Within the Vietnamese Canadian community, these "economic" migrants are thought to have benefitted in socialist Vietnam following the end of the war and have now come to Canada to enjoy an established Vietnamese community built by the "legitimate" refugees. The lingering intra-community tensions from the Vietnam War exacerbate class discrimination as the refugee cohort- "boat people" who experienced horrific losses and hardship-are now faced with a growing mass of arrivals who stayed in Vietnam after the war and might have even prospered. Yet these later arrivals may have experienced other kinds of losses and hardships in postwar Vietnam, but their experiences are excluded. The singular construction of Vietnamese refugees as "wretches to riches" in the literature contributes to the division of the Vietnamese Canadian community. Those who can narrate a past of suffering under communism are taken to be the rightful Vietnamese Canadians, and those who cannot, remain unknown.

\section{Impact of Conflicts}

Participants reported that the results of intra-group differences are self-exclusion, discrimination, and the threat of violence. Self-exclusion occurred across identities. Participants from North Vietnam and recent migrants shared instances of exclusion in their daily work experiences or while seeking services. Often the other person simply refused contact. Participants reported measures of self-imposed exclusion to guard against potential negative interactions. Thu, an elderly South Vietnamese woman shared how she felt about her North Vietnamese peers: "When I saw a friend of mine posting a red flag [of present-day Vietnam] or Ho Chi Minh pictures on Facebook, I was initially very angry ... But then I thought over and I thought that I was luckily from the South ... They are living there, they had another education. So they are not like me. Forget it, those damn people. That's the respect of the differences." 43 Different experiences and perspectives in this case are not shared or discussed to seek common ground but rather are simply avoided.

An extreme impact of community division that participants reported is the threat of violence. Participants heard the threat or incidences of violence but also internalized it in "jokes" made in the focus groups. At a social gathering among those mostly from North Vietnam, Tam recounted that when the current official flag of Vietnam was displayed, "I heard that somebody had come and explained to them that our community was of the refugees and here is the refugee community. If you do things that irritate people's eyes (ngúa măt), you might get in trouble. So you should not show red flags here. After the talk, then the red flags were removed." 44 Mai shared a similar story: "When I went to school in New Brunswick, we decided to choose which flag for a diversity day ... Most of the people studying in LINC [Language Instruction for Newcomers to Canada] are new, but they are afraid of using the red flag because it can cause conflict. However, we finally decide that we will use the flag, which is accepted by international bodies. But I remember one of my friends was saying, 'If you're in Quebec or the United States, you'd be dead for using this flag."'45

The threat of violence was experienced by participants but also internalized as fear. The most common and most visible transgressions are the display of the flag of presentday Vietnam, the display of pictures of the leaders of socialist Vietnam such as Ho Chi Minh, and the public singing or playing of "liberation" music created in Vietnam after 1975. There has been no documented incidence of such transgressions in Canada, but events in the United States demonstrate the strong and violent reaction that can ensue within the diaspora. In 1999 the owner of an electronics store in Westminister, California, displayed the current flag of Vietnam and a picture of Ho Chi Minh in his storefront. There were massive demonstrations, verging on riots, until the police arrested the storeowner on charges of media piracy. 46 While this has yet to happen in Canada, the threat of violence alone warrants caution and avoidance of Vietnamese community engagement at organized events and activities.

The 28 participants in this small study reported either having been socially excluded, deliberately avoiding interaction with other Vietnamese Canadians, or hearing implied threats of violence against those who might transgress 
community norms (for example, which flag to display, which national hero to honour, and even what type of music to play in public). This is a small but troubling snapshot of the range of experiences Vietnamese Canadians have had within their community. Those who struggle within this racialized migrant community, vulnerable to systemic barriers, might resist seeking informal supports within a community they do not trust. Yet all of this has been hidden within the social work literature that celebrates the narrative of Vietnamese as exceptional in their refugee plight and successful resettlement.

\section{Implications}

A critical reading of the social work literature on Vietnamese Canadians reveals a flat representation of this group as exceptional refugees who came to Canada through legitimate means and thrived under capitalism. Yet a local community-based study of Vietnamese Canadians in Toronto contests this narrow identity. Participants reported core differences within the Vietnamese community in Toronto as lingering effects of the Vietnam War based on markers of regional origin, class, and period of migration. These differences interact with and complicate one another to push back against the identity of "boat people." These differences and consequences are related to the events of the war in Vietnam that lead to participants' arrival to Canada either as refugees or migrants.

This discussion is intended to prompt further inquiry into the presumed homogeneity of the Vietnamese refugee group and their apparently successful settlement and adaptation. The social work literature, a powerful operation of knowledge production, is implicated in the marginalization of this group in upholding Vietnamese Canadians as exceptional refugees. Further studies are needed to examine the lived experiences of refugee and migrant groups who arrive to Canada with the baggage of civil war and local conflicts who are now expected to settle and adapt with one another under multiculturalism. The Vietnamese community in Canada is one of many groups who work to reconcile a history of conflict and division by civil war. This reconciliation is hindered, if not outright challenged, by dominant producers of knowledge such as the social work literature. This literature informs the very educators and researchers who hope to support this group, yet it continues to see Vietnamese Canadians as refugee "boat people" of the 1980s, thus missing experiences that are outside of this identity.

\section{Notes}

1 James C. Hathaway, "Refugee Solutions, or Solutions to Refugeehood?," Refuge: Canada's Journal on Refugees 24, no. 2 (2007): 3-10.
2 Statistics Canada, "National Household Survey: Immigration and Ethnocultural Diversity," 2013, issue 2011028, catalogue no. 99-010-X2011028," http://www5.statcan. gc.ca/olc-cel/olc. action?objId=99-010-X2011028\&objType $=46 \&$ lang $=$ en $\&$ limit $=0$.

3 Employment and Immigration Canada, "Indochinese Refugees: The Canadian Response, 1979 and 1980," Canadian Immigration Historical Society, http://cihs-shic.ca/ wp-content/uploads/2015/o3/Indochinese-Refugees-CdnResponse-report-ENG.pdf.

4 Employment and Immigration Canada, "Immigration Statistics 1966-1996," Library and Archives Canada, http:// epe.lac-bac.gc.ca/100/202/301/immigration_statistics-ef/ index.html; Statistics Canada, "Table 051-0006: Immigrants to Canada, by Country of Last Permanent Residence, Quarterly (Persons)," CANsim (database), http:// www5.statcan.gc.ca/cansim/a26?lang=eng\&retrLang=en g\&id=0510006\&pattern=vietnam\&csid=; Citizen Immigration Canada, "Facts and Figures 2014-Immigration Overview: Permanent Residents," http://www.cic.gc.ca/ english/resources/statistics/facts2014/permanent/10.asp.

5 Statistics Canada, "NHs Profile, Toronto, CMA, Ontario, 2011," http://www12.statcan.gc.ca/nhs-enm/2011/dp-pd/ prof/details/page.cfm?Lang $=\mathrm{E} \& \mathrm{GeO} 1=\mathrm{CMA} \& \operatorname{Code} 1=535 \&$ Data $=$ Count $\&$ SearchText $=$ Toronto\&SearchType $=$ Begins $\&$ Search $P R=01 \& A 1=A l l \& B 1=A l l \&$ Custom $=\& \mathrm{TABID}=1$.

6 City of Toronto, "Backgrounder 2011 Census: Language," City of Toronto, 25 October 2012.

7 Ibid.

8 Statistics Canada, "2011 Census of Population: Linguistic Characteristics of Canadians," catalogue no. 98-314X20110001," Minister of Industry, October 2012.

9 Izumi Sakamoto, "Changing Images and Similar Dynamics: Historical Patterning of Foreignness in the Social Work Profession," in The Concept of Foreign: An Interdisciplinary Dialogue, ed. Rebecca Saunders, 237-79 (Oxford: Lexington Books, 2003); Mariana Valverde, The Age of Light, Soap, and Water: Moral Reform in English Canada, 1885-1925 (Toronto: University of Toronto Press, 2008).

10 A. Ka Tat Tsang, "Representation of Ethnic Identity in North American Social Work Literature: A Dossier of the Chinese People," Social Work 46, no. 3 (2001): 229-43.

11 Loan T.Phan,Edil TorresRivera, and Janice Roberts-Wilbur, "Understanding Vietnamese Refugee Women's Identity Development from a Sociopolitical and Historical Perspective," Journal of Counseling and Development 83, no. 3 (2005): 305.

12 Morton Beiser, Strangers at the Gate: The "Boat People"'s First Ten Years in Canada (Toronto: University of Toronto Press, 1999), 170.

13 Kwok B. Chan and Doreen Marie Indra, Uprooting, Loss and Adaptation: The Resettlement of Indochinese Refugees in Canada (Ottawa: Canadian Public Health Association, 1987), 1. 
14 Sean P. Hier and Joshua L. Greenberg, "Constructing a Discursive Crisis: Risk, Problematization and Illegal Chinese in Canada," Ethnic and Racial Studies 25, no. 3 (2002): 490-513; Maggie Ibrahim, "The Securitization of Migration: A Racial Discourse," International Migration 43, no. 5 (2005): 163-87.

15 Rebecca Allen and Harry H. Hiller, “The Social Organization of Migration: An Analysis of the Uprooting and Flight of Vietnamese Refugees," International Migration 23, no. 4 (1985): 439-52.

16 See Ashley Bradimore and Harald Bauder, "Mystery Ships and Risky Boat People: Tamil Refugee Migration in the Newsprint Media," Canadian Journal of Communication 36, no. 4 (2011): 637-61, for an overview of the media's representation of the 1999 Fujian and the 2009 Tamil refugees as bogus refugees; and Alison Mountz, "Embodying the Nation-State: Canada's Response to Human Smuggling," Political Geography 23, no. 3 (2004): 323-45, for a critical analysis of Canada's immigration policy's responses in detaining these refugees.

17 Vinh Nguyen, "Refugee Gratitude: Narrating Success and Intersubjectivity in Kim Thúy's Ru," Canadian Literature 219 (2013): 17.

18 Himani Bannerji, The Dark Side of the Nation: Essays on Multiculturalism, Nationalism and Gender (Toronto: Canadian Scholars', 200o); Eva Mackey, The House of Difference: Cultural Politics and National Identity in Canada (Toronto: University of Toronto Press, 2002); Sunera Thobani, Exalted Subjects: Studies in the Making of Race and Nation in Canada (Toronto: University of Toronto Press, 2007).

19 Renisa Mawani, "Genealogies of the Land: Aboriginality, Law, and Territory in Vancouver's Stanley Park," Social \& Legal Studies 14, no. 3 (2005): 315-39; Daiva Stasiulis and Radha Jhappan, "The Fractious Politics of a Settler Society: Canada," in Unsettling Settler Societies: Articulations of Gender, Race, Ethnicity and Class, ed. Daiva Stasiulus and Nira Yuval-Davis, 95-131 (London: Sage Publications, 1995); Jean Burnet, "Myths and Multiculturalism," Canadian Journal of Education / Revue canadienne de l'éducation 4, no. 4 (1979): 43-58.

20 Eve Haque, Multiculturalism within a Bilingual Framework: Language, Race, and Belonging in Canada. (Toronto: University of Toronto Press, 2012).

21 Tan Phan, "Life in School: Narratives of Resiliency among Vietnamese-Canadian Youths," Adolescence 38, no. 151 (2003): 555; Louis-Jacques Dorais, "Refugee Adaptation and Community Structure: The Indochinese in Quebec City, Canada," International Migration Review 25, no. 3 (1991): 551-73; Phyllis J. Johnson, "Credit Card Practices of Vietnamese and Laotian Newcomers to Canada: A 10-Year Longitudinal Perspective," Journal of Family and Economic Issues 28, no. 2 (2007): 227-46.
22 Randal Montgomery, "Predicting Vietnamese Refugee Adjustment to Western Canada," International Migration 29, no. 1 (1991): 89-117.

23 Morton Beiser, Phyllis J. Johnson, and R. Jay Turner, "Unemployment, Underemployment and Depressive Affect among Southeast Asian Refugees," Psychological Medicine 23, no. 3 (1993): 731-43.

24 Montgomery, "Predicting Vietnamese Refugee Adjustment," 94.

25 Morton Beiser, "Refugees in Canada," Canadian Issues 1 (2004): 54-6.

26 Hijin Park, "Being Canada's National Citizen: Difference and the Economics of Multicultural Nationalism," Social Identities 17, no. 5 (2011): 643-63; Jane Ku, "Postcolonial Incorporation of the Different Other," Crossings: Journal of Migration \& Culture 3, no. 1 (2012): 33-51.

27 Gordon Pon, "Importing the Asian Model Minority Discourse into Canada: Implications for Social Work and Education," Canadian Social Work Review / Revue canadienne de service social 17, no. 2 (2000): 286.

28 Mimi Thi Nguyen, The Gift of Freedom: War, Debt, and Other Refugee Passages (Durham, NC: Duke University Press, 2012).

29 Morton Beiser, Samuel Noh, Feng Hou, Violet Kaspar, and Joanna Rummens, “Southeast Asian Refugees' Perceptions of Racial Discrimination in Canada," Canadian Ethnic Studies 33, no. 1 (2001): 46-69.

30 Phan, "Life in School," 558.

31 Clarry Lay and Thao Nguyen, "The Role of AcculturationRelated and Acculturation Non-Specific Daily Hassles: Vietnamese-Canadian Students and Psychological Distress," Canadian Journal of Behavioural Science 30, no. 3 (1998): 171-81.

32 Catherine L. Nolin, "Transnational Ruptures and Sutures: Questions of Identity and Social Relations among Guatemalans in Canada," GeoJournal 56, no. 1 (2002): 59-67.

33 Yen Le Espiritu, "Beyond the 'Boat People': Ethnicization of American Life," Amerasia Journal 15, no. 2 (1989): 49-67.

34 Yen Le Espiritu, Body Counts: The Vietnam War and Militarized Refugees (Berkeley, CA: University of California Press, 2014).

35 Xuân, focus group \#3, 28 April 2013.

36 Phủ, individual interview \#3, 23 May 2013.

37 An, individual interview \#8, 10 July 2013.

38 Hùng, focus group \#2, 23 March 2013.

39 Kimberly Kay Hoang, Dealing in Desire: Asian Ascendancy, Western Decline, and the Hidden Currencies of Global Sex Work (Berkeley, CA: University of California Press, 2015).

40 Minh, individual interview \#2, 15 May 2013.

41 Phủ, focus group \#4, 4 June 2013.

42 Hai, focus group \#2, 23 March 2013.

43 Thu, individual interview \#6, 10 June 2013.

44 Tam, individual interview \#4, 23 May 2013. 
45 Mai, focus group \#3, 28 April 2013.

46 Further analysis of this incident can be found over several articles in Linda Trinh Vô, ed., "Vietnamese Americans: Diaspora \& Dimensions," Amerasian Journal 29, no. 1

Anh Ngo is a PhD candidate in the School of Social Work at York University. She may be contacted at anhngo@yorku.ca. (2003).

(C) Ahn Ngo, 2016. This open-access work is licensed under a Creative Commons Attribution-NonCommercial 4.0 International License, which permits use, reproduction and distribution in any medium for non-commercial purposes, provided the original author(s) are credited and the original publication in Refuge: Canada's Journal on Refugees is cited. 